\title{
Identifikasi Perubahan Tataguna Lahan di Sekitar Calon Tapak PLTN Kabupaten Bengkayang, Kalimantan Barat
}

\author{
Mudjiono*1, Siti Alimah ${ }^{1}$, Heni Susiati ${ }^{1}$ \\ ${ }^{1}$ Pusat Kajian Sistem Energi Nuklir, BATAN, JI. Kuningan Barat, Jakarta Selatan, Indonesia
}

\begin{tabular}{l}
\hline INFORMASI ARTIKEL \\
\hline RiwayatArtikel: \\
Diterima: \\
25 November 2020 \\
Diterima dalam bentuk revisi: \\
13 Desember 2020 \\
Disetujui: \\
19 Desember 2020
\end{tabular}

Kata kunci:

Tata guna lahan

PLTN

Bengkayang

Citra satelit

\begin{abstract}
ABSTRAK
IDENTIFIKASI PERUBAHAN TATAGUNA LAHAN DI SEKITAR CALON TAPAK PLTN KABUPATEN BENGKAYANG, KALIMANTAN BARAT. Rencana pembangunan Pembangkit Listrik Tenaga Nuklir (PLTN) telah dipertimbangkan oleh pemerintah daerah di kabupaten Bengkayang, Kalimantan Barat, sebagai salah satu opsi untuk menambah pasokan energi listrik di wilayah tersebut. Evaluasi data penggunaan lahan yang ada di Kabupaten Bengkayang sebelum program PLTN dibangun sebagai data base, merupakan salah satu persyaratan yang perlu dipertimbangkan. Pembangunan PLTN akan merubah tataguna lahan dan tata ruang di Kabupaten Bengkayang, Kalimantan Barat. Penggunaan lahan untuk PLTN harus memenuhi persyaratan agar menjamin keselamatan penduduk dan lingkungan sekitar. Metode yang digunakan dalam kajian ini berbasis studi literatur dengan mengumpulkan data dan peraturan terkait, dan interpretasi citra Landsat tahun 2015 dan 2019. Tujuan studi adalah mengetahui database penggunaan lahan dan perubahan tata guna lahan di Kabupaten Bengkayang, Kalimantan Barat. Sinergi pengumpulan data penggunaan lahan antara interpretasi data penggunaan lahan dari data citra satelit dan data statistik akan memperkuat dalam pelaksanaan analisis dampak perkembangan terjadinya perubahan penggunaan lahan. Hasil kajian diperoleh bahwa penggunaan lahan di sekitar tapak pada radius $1 \mathrm{~km}$ adalah untuk pemukiman penduduk $53.176 \mathrm{~m}^{2}$, lahan terbuka $175.021 \mathrm{~m}^{2}$, perkebunan $2.001 .696 \mathrm{~m}^{2}$, perairan darat $56.718 \mathrm{~m}^{2}$ dan laut $953.389 \mathrm{~m}^{2}$. Dengan kehadiran PLTN, tutupan lahan dominan berupa perkebunan secara peruntukan akan beralih ke industri. Konversi pemanfaatan lahan akan menyebabkan tumbuh dan berkembang sarana dan prasarana untuk perkantoran, perumahan, pendidikan, kesehatan, peribadatan, pemukiman, keamanan dan sarana pendukung lainnya. Interpretasi citra Landsat, menunjukkan perubahan lahan antara tahun 2015 sampai tahun 2019 tidak terlihat adanya perubahan penggunaan lahan yang signifikan.
\end{abstract}

\begin{abstract}
IDENTIFICATION OF CHANGES IN LAND USE AROUND CANDIDATE SITE OF NPP BENGKAYANG DISTRICT, WEST KALIMANTAN. The local government in Bengkayang district, West Kalimantan has considered the plan to build a Nuclear Power Plant (PLTN) as an option to increase the supply of electrical energy in the region. Evaluation of existing land use data in Bengkayang Regency before the PLTN program was built as a database, is one of the requirements that need to be considered. PLTN construction will change land use and spatial planning in Bengkayang Regency, West Kalimantan. Land use for nuclear power plants must meet the requirements to ensure the safety of residents and the surrounding environment. The method used in this study is based on literature studies by collecting data and related regulations, and interpretation of Landsat imagery in 2015 and 2019. The study objective was to determine the database of land use and land use change in Bengkayang Regency, West Kalimantan. The synergy of collecting land use data between the interpretation of land use data from satellite imagery data and statistical data will strengthen the analysis of the development impact of land use change. The results of the study show that the land use around the site at a radius of $1 \mathrm{~km}$ is for residential areas of $53,176 \mathrm{~m}^{2}$, open land $175,021 \mathrm{~m}^{2}$, plantations $2,001,696 \mathrm{~m}^{2}$, land waters $56,718 \mathrm{~m}^{2}$, and sea $953,389 \mathrm{~m}^{2}$. With the presence of NPP's, the dominant land cover in the form of plantations will shift to industry. Land use conversion will cause the growth and development of facilities and infrastructure for offices, housing, education, health, worship, housing, security, and other supporting facilities. Interpretation of Landsat imagery, showing that land changes between 2015 and 2019 do not show any significant changes in land use.

Keywords: Land use, NPP, Bengkayang, satellite imagery
\end{abstract}

\section{PENDAHULUAN}

Pengembangan kawasan pembangkit listrik yang merupakan salah satu opsi dalam mengatasi masalah kebutuhan listrik di
Kalimantan Barat akan diprogramkan, diantaranya untuk dibangun PLTN. Program ini dilaksanakan untuk menjamin keamanan energi 
di Kalimantan Barat. Sesuai data PLN, disebutkan bahwa Kalimantan Barat sampai saat ini baru mempunyai daya terpasang sebesar 742 MW dan proyeksi kebutuhan (demand projection) listrik sampai tahun 2027 sebesar 1.564,570 MW [1]. Masyarakat modern menggunakan energi listrik dalam jumlah besar. Peningkatan jumlah penduduk dan pembangunan akan meningkatkan penggunaan energi[2]. PLTN dapat menyediakan pasokan listrik yang andal, dengan emisi karbon yang sangat rendah.

Kabupaten Bengkayang Kalimantan Barat merupakan salah satu wilayah yg telah dikaji berdasar aspek keselamatan dan non keselamatan untuk calon lokasi pembangunan PLTN. Hasil penelitian yang telah dilakukan telah diperoleh 9 tapak terpilih sebagai tapak potensial PLTN di Kalimantan Barat [3] [4].

Hasil studi lanjutan, sesuai permintaan BAPPEDA Provinsi Kalimantan Barat dengan surat No. 050/749/SPW-BAPPEDA tahun 2019 diperoleh lokasi calon tapak untuk prototipe PLTN di Pantai Gosong dan Pulau Semesa, Desa Sungai Raya, Kecamatan Sungai Raya Kepulauan, Kabupaten Bengkayang[5]. Salah satu kegiatan yang telah dilakukan adalah kajian terkait dampak rencana pembangunan PLTN tersebut terhadap pola pemanfaatan lahan ditinjau dari ketersediaan lahan, disesuaikan dengan rencana tata ruang dalam kebutuhan sarana dan prasarana.

Evaluasi penggunaan lahan sangat diperlukan dalam evaluasi tapak PLTN. Perencanaan pembangunan dan pengembangan program PLTN memerlukan dukungan data dan informasi kewilayahan (keruangan/ spasial) yang komprehensif dan terbaru. Salah satu informasi yang sangat penting adalah data penutupan/penggunaan lahan Kawasan PLTN di kabupaten Bengkayang[3][6][7]. Pada waktu dilakukan pemilihan tapak PLTN di pesisir Kalimantan Barat, data penggunaan lahan masih menggunakan data tahun 2014[3][4]. Oleh karena itu untuk mengetahui perkembangan perubahan penggunaan lahan saat ini, penelitian ini sangat diperlukan. Permasalahan lingkungan dalam pemilihan tapak termasuk juga terkait dengan dampak potensial dari pembangunan dan pengoperasian PLTN ada kaitannya juga dengan kondisi penggunaan lahan yang akan dilakukan evaluasi lebih lanjut[8][9]. Oleh karena itu identifikasi perubahan penggunaan lahan setelah dilakukan pemilihan tapak awal PLTN untuk mendapatkan gambaran sesungguhnya terkait status terkini untuk memperkuat keberterimaan tapak potensial PLTN dalam evaluasi lebih lanjut [9] [10] [11].

Penggunaan data citra satelit mempunyai keunggulan dalam ketersediaan data spasial penggunaan lahan. Data citra satelit digunakan dalam pemetaan penggunaan lahan sebagai database yang harus dipersiapkan dalam perencanaan pembangunan PLTN[7]. Di samping itu analisis dengan interpretasi multiyear untuk melihat perubahan perkembangan penggunaan lahan suatu daerah juga dapat diidentifikasi dengan sistematis dan cepat[7][12].

Tujuan penelitian ini adalah untuk mengetahui pola penggunaan lahan dan perubahannya sebagai data base dalam persiapan pembangunan PLTN di Kabupaten Bengkayang, Kalimantan Barat. Identifikasi penggunaan lahan dan perubahannya dilakukan dengan interpretasi dari citra satelit resolusi sedang Landsat ETM 7 tahun 2015 dan 2019. Selanjutnya perubahan lahan yang diperoleh disinergikan dengan data hasil sensus oleh BPS yang dilakukan pada tahun 2014 dan 2015 sehingga hasil analisis perubahan penggunaan lahan akan lebih akurat[[13][14].

Setiap tahun penggunaan lahan suatu daerah mengalami perubahan, hal ini bisa disebabkan oleh berbagai faktor, diantaranya karena jumlah penduduk yang meningkat, ataupun telah dilakukan pembangunan di daerah tersebut. Perubahan penggunaan lahan saat ini sangat didominasi dari dampak akibat kegiatan ulah manusia bila dibandingkan dengan akibat faktor alam[15].

Analisis perubahan penggunaan lahan dengan data spasial yang bersifat temporal sangat bermanfaat, hal ini sangat penting untuk mengetahui daerah-daerah yang telah mengalami perubahan penggunaan lahan dan akibatnya[15][16][17], serta faktor penting dalam manajemen penggunaan lahan[18]. Identifikasi penggunaan lahan berbasis spasial telah memberi nilai yang akurat dan perkembangan dalam pemanfaatan interpretasi dengan penginderaan jauh telah mempermudah pengguna untuk interpretasi secara fotografik [19]. 


\section{TATAGUNA LAHAN DI SEKITAR CALON TAPAK PLTN}

Penentuan lokasi tapak untuk prototipe PLTN di Kalimantan Barat didasarkan berbagai aspek, sesuai dengan persyaratan dari BAPETEN[20] dan IAEA[21].

Berbagai jenis PLTN di dunia, sejumlah besar adalah jenis PWR (Pressurized Water Reactor $P W R$ ) yang merupakan reaktor berpendingin air ringan yaitu sebanyak 298 unit dan yang lain adalah BWR, FNR, GCR, LWGR dan PHWR[22]. Jenis PLTN yang direncanakan akan dibangun di Kalimantan Barat adalah PWR dengan daya kecil, diantaranya yang menjadi kandidat adalah ACP100 100 MWe, SMART 330 MWth, dan NuScale 60 MWe[1].

Sebagaimana lahan untuk PLTN lainnya, lahan untuk tapak prototipe PLTN Kalimantan Barat adalah bukan lahan untuk menopang kehidupan, bukan lahan pertanian ataupun yang direncanakan untuk pertanian/peternakan, juga bukan lahan untuk komersial, maupun perumahan atau rekreasi[11]. Hal tersebut terkait dengan keberterimaan parameter desain. Penetapan tapak PLTN dapat memberikan perubahan tata guna lahan, namun jika tidak menyebabkan perubahan kondisi rona lingkungan hidup awal, maka memenuhi kriteria pengelolaan lingkungan hidup [23].

Tataguna lahan merupakan pengelompokan lahan berdasar status dan penggunaan lahan, seperti lahan untuk pertanian, peternakan, industri dan lain sebagainya[13]. Penggunaan lahan dapat merubah umur operasi instalasi PLTN[14]. Desain instalasi dan pengoperasian yang tepat dapat mengurangi dampak pada penggunaan lahan dan dampak estetika di tapak dan lingkungan terdekat, baik yang disebabkan konstruksi, operasi, jalur transmisi maupun transportasi[24]. Namun keberterimaan tapak PLTN di masa yang akan datang juga tergantung pada dampak perkembangan industri, komersial lain dan pengembangannya[25].

\section{METODOLOGI}

\subsection{Lokasi Penelitian}

Penelitian ini dilakukan di Kabupaten Bengkayang, Provinsi Kalimantan Barat, dengan letak geografis di $0^{0} 33^{\prime} 00^{\prime \prime}-1^{0} 33^{\prime} 00^{\prime \prime}$ Lintang Utara dan 108 $39^{\prime} 00^{\prime \prime}$ - 110 10'00" Bujur Timur. Secara administratif lokasi penelitian disajikan pada Gambar 1. Sebagian besar wilayah Kabupaten Bengkayang adalah daratan dengan total luas mencapai 5.036,10 $\mathrm{km}^{2}$. Ditinjau dari administrasi kewilayahan, Kabupaten Bengkayang terdiri atas 17 kecamatan yang meliputi 2 kelurahan, 122 desa dan 320 dusun. Lokasi calon tapak prototipe PLTN di Kalimantan Barat PLTN diperlihatkan dalam Gambar 2. Calon tapak tersebut terletak di Desa Sungai Raya, Kecamatan Sungai Raya Kepulauan, yang mempunyai luas wilayah desa $28,42 \mathrm{~km}^{2}[15]$.

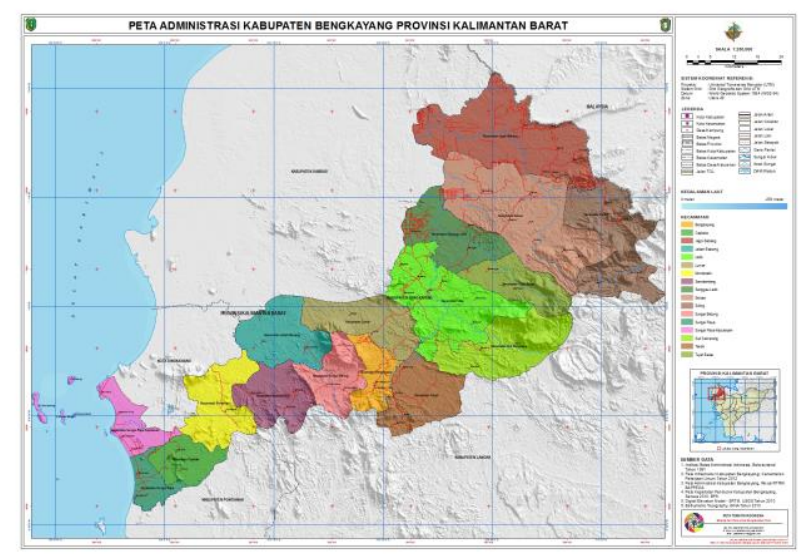

Gambar 1. Peta Administrasi Kabupaten Bengkayang [26].

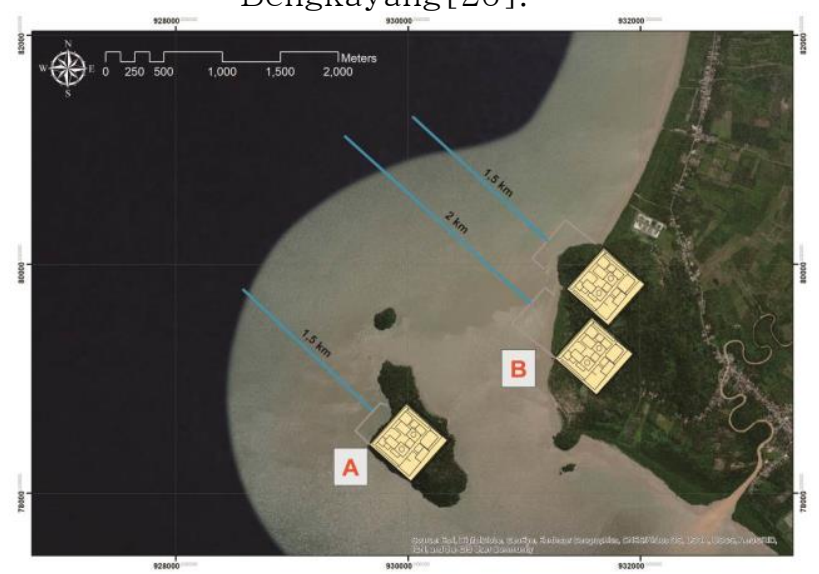

Gambar 2. Lokasi Calon Tapak PLTN Prototipe di Kalimantan Barat[5].

\subsection{Bahan dan Alat}

Pada penelitian ini digunakan data primer dan sekunder. Data primer diperoleh melalui konfirmasi lapangan, sedangkan data sekunder diperoleh melalui penelusuran data spasial dan statistik di berbagai instansi pemerintah, yaitu Badan Informasi Geospasial (BIG), Badan Pusat Statistik (BPS), dan Bappeda Kabupaten maupun 
Provinsi Kalimantan Barat. Untuk pengolahan data spasial digunakan software Arc GIS.

Bahan yang digunakan dalam penelitian antara lain data spasial dari Interpretasi data citra Landsat Peta Penggunaan Lahan tahun 2015 dan 2019.

\subsection{Identifikasi Penggunaan Lahan}

Identifikasi penggunaan / tutupan lahan diawali dengan interpretasi citra Landsat tahun 2015 dan 2019. Data diambil dari data yang digunakan untuk menyusun buku Rencana Tata Ruang Rencana Wilayah (RTRW) Kabupaten Kalimantan Barat

\section{HASIL DAN PEMBAHASAN}

Perubahan fungsi Kawasan dengan sarana dan prasarana pendukungnya untuk PLTN memerlukan konversi lahan dari perkebunan menjadi industri. Fungsi Kawasan berubah menjadi Kawasan Strategis Provinsi yang penataan ruangnya diprioritaskan karena mempunyai pengaruh sangat penting dalam lingkup provinsi terhadap ekonomi, sosial, budaya, dan/atau lingkungan. Perubahan peruntukan lahan dari dominan perkebunan beralih ke industri akan menyebabkan tumbuh dan berkembang sarana dan prasarana diantaranya kebutuhan lahan untuk perkantoran, perumahan, pendidikan, kesehatan, peribadatan, pemukiman, keamanan dan sarana pendukung lainnya.

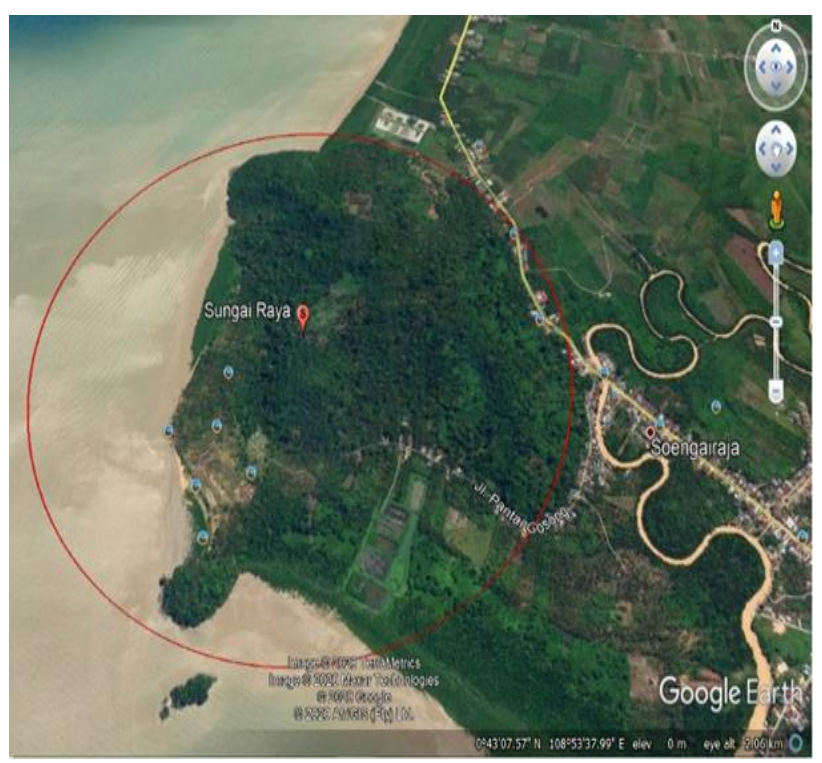

Gambar 3. Penampakan Lahan di Sekitar Lokasi Calon Tapak PLTN Radius $1 \mathrm{~km}$.
Penampakan Lahan di sekitar Lokasi Calon Tapak PLTN radius $1 \mathrm{~km}$ diperlihatkan dalam Gambar 3. Selanjutnya, dilakukan analisis tutupan lahan di sekitar calon tapak prototipe PLTN tersebut dan hasil analisis memperlihtatkan bahwa penggunaan lahan didominasi perkebunan dan area yang belum dimanfaatkan, seperti terlihat pada Tabel 1.

Tabel 1. Tutupan Lahan Radius 1 Km (Desa Sungai Raya)

\begin{tabular}{|l|l|l|}
\hline No. & \multicolumn{1}{|c|}{$\begin{array}{c}\text { Penggunaan } \\
\text { Lahan }\end{array}$} & Luas $\left(\mathrm{m}^{2}\right)$ \\
\hline 1 & Pemukiman & 53.176 \\
\hline 2 & Lahan Terbuka & 75.021 \\
\hline 3 & Perkebunan & 2.001 .696 \\
\hline 4 & Perairan Darat & 56.718 \\
\hline 5 & Perariran Laut & 963.389 \\
\hline
\end{tabular}

Pada waktu dilakukan ground check lapangan pada akhir bulan Nopember 2019 didapati bahwa perkebunan di sekitar calon tapak didominasi tanaman kelapa. Mengacu hasil penelitian yang telah dilakukan oleh Musa Miantono dan kawan-kawan, berdasarkan tipe penggunaan lahan dimana tapak potensial PLTN diidentifikasi layak untuk dibangun, pada tahun 2018 terdiri atas kebun campuran dengan luasan 1.584,75 Ha, semak belukar sebesar 158,64 Ha, dan kebun kelapa sawit sebesar 2.116,83 Ha[24].

Analisis kebutuhan lahan mengacu pada Pedoman Teknik Analisis Tata Cara dan Pedoman Teknik Baku Perencanaan Tata Ruang yang dikeluarkan oleh Departemen Pekerjaan Umum. Pola distribusi peruntukan ruang dalam suatu wilayah meliputi peruntukan ruang untuk fungsi lindung dan fungsi budidaya. Menurut Peraturan Daerah Kabupaten Bengkayang Nomor 7 tahun 2014 bahwa Kabupaten Bengkayang adalah Pusat Kegiatan Wilayah Promosi (PKWP) yang akan dipromosikan menjadi Pusat Kegiatan Wilayah (PKW) dengan fungsi melayani kegiatan skala propinsi atau beberapa kabupaten/kota.

Calon tapak PLTN berada di kecamatan Sungai Raya Kepulauan yang sebelumnya merupakaan pemekaran dari kecamatan Sungai Raya. Kecamatan Sungai Raya (sebelum terjadi pemekaran) merupakan satu-satunya kecamatan yang berada di wilayah pesisir yang berada di posisi paling Barat wilayah Kabupaten Bengkayang. Wilayah pesisir ini 
berbatasan dengan laut Natuna dan mempunyai Panjang garis pantai sebesar 68,5 km[27].

Penggunaan lahan wilayah pesisir Kabupaten Bengkayang masih didominasi oleh hutan mangrove dan diperuntukan sebagai zona Kawasan Ekonomi (Gambar 4)[28][29]. Telah banyak penelitian yang melakukan manfaat potensial ekosistem mangrove sebagai penyimpan karbon dalam rangka mitigasi pemanasan global[30]. Di samping itu juga ada beberapa wilayah pulau-pulau kecil di Kabupaten Bengkayang yang sudah direkomendasikan sebagai wilayah Kawasan konservasi dan Wisata Alam Laut
Bengkayang[28]. Hal ini diperkuat dengan telah terbitnya Peraturan Daerah Provinsi Kalimantan Barat, Nomor 1 Tahun 2019 tentang Rencana Zonasi Wilayah Pesisir dan PulauPulau Kecil Provinsi Kalimantan Barat 20182038, peruntukan Kawasan pesisir kecamatan Sungai Raya Kepulauan (Gambar 3, 4,dan 5) [29] [28].

Perubahan penggunaan lahan di kabupaten secara keseluruhan pada tahun 2014 sampai 2019, hasil perkembangannya digambarkan pada Gambar 6.
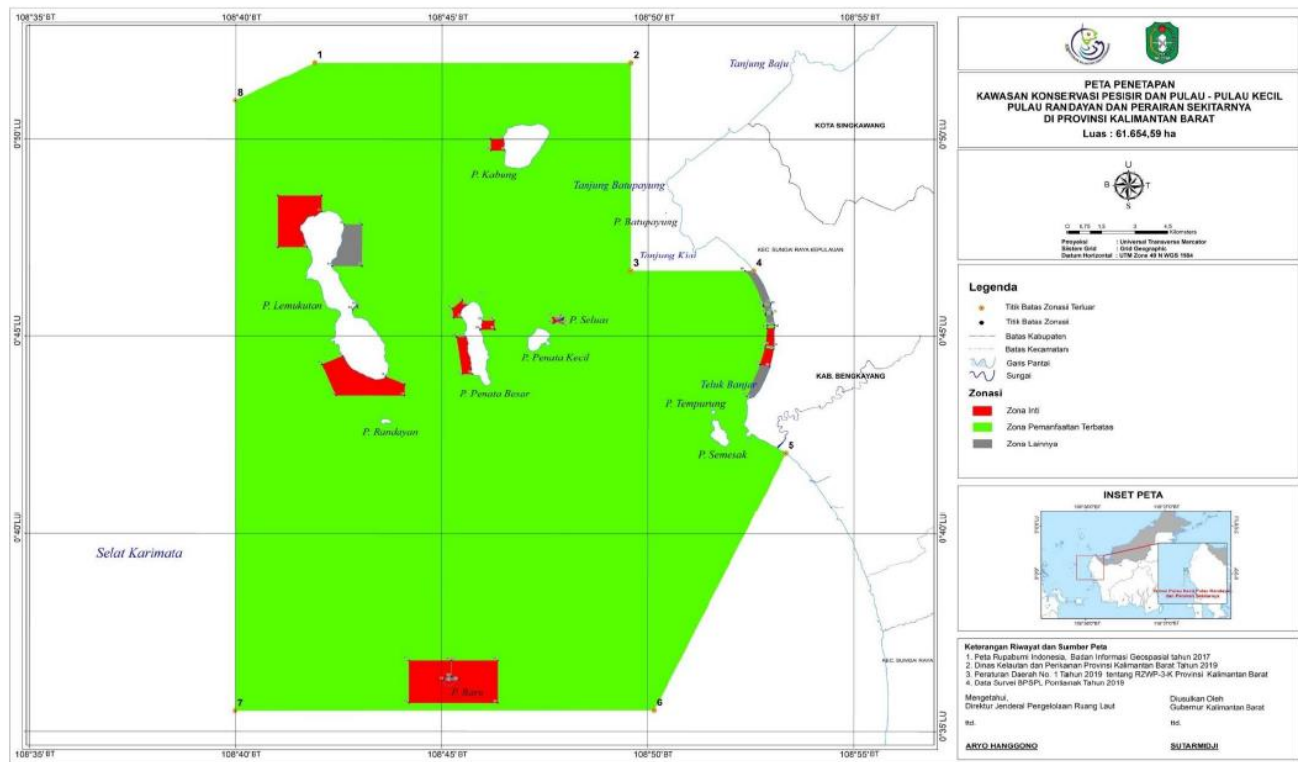

Gambar 4. Peta Konservasi Pesisir dan Pulau Kecil Pulau Randayan dan Perairan sekitarnya

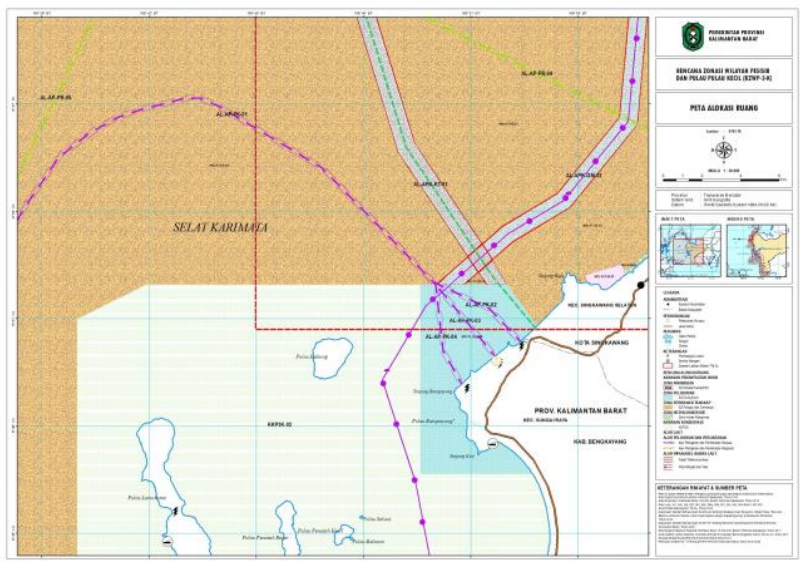

Gambar 5a. Peta Alokasi Ruang Pesisir Sekitar Tapak PLTN, kecamatan Sungai Raya Kepulauan Bagian Utara29].

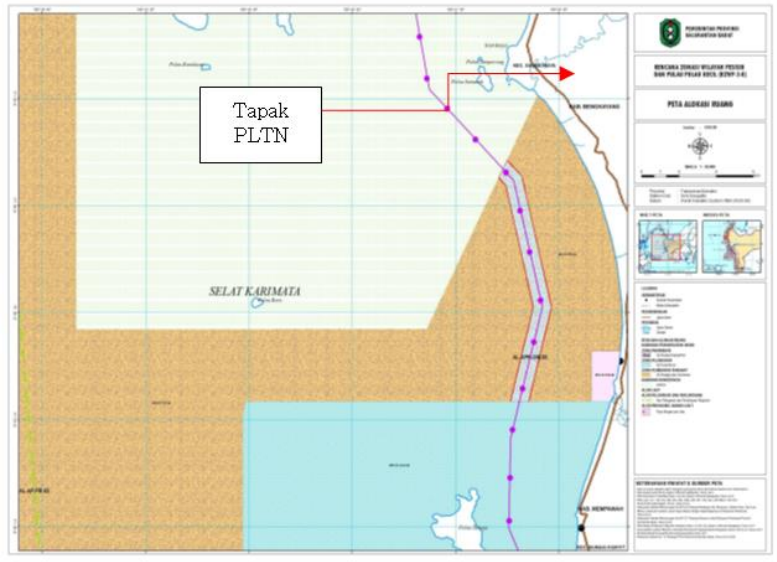

Gambar 5b. Peta Alokasi Ruang Pesisir Sekitar Tapak PLTN, kecamatan Sungai Raya Kepulauan Bagian Selatan[29]. 


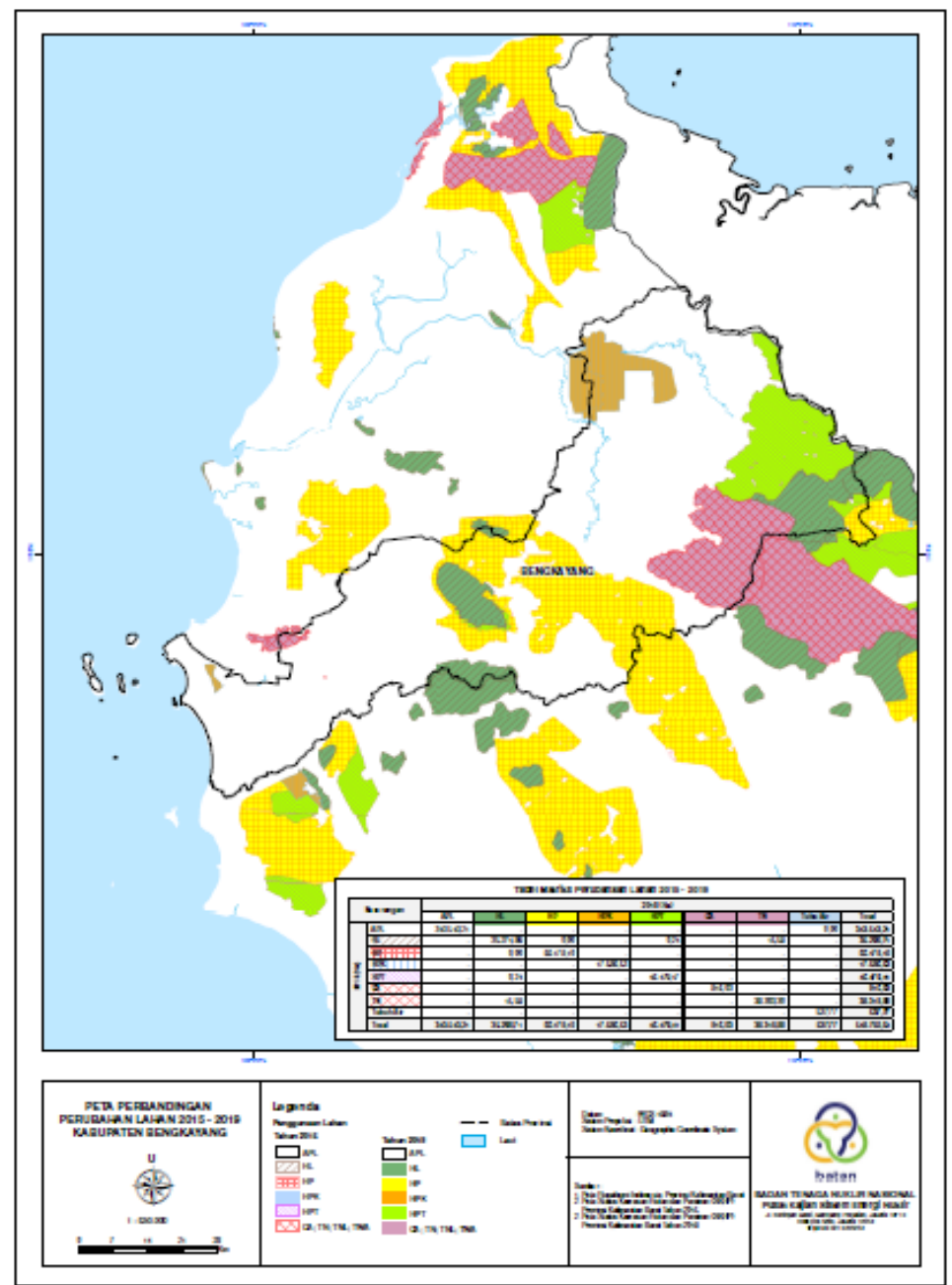

Gambar 6. Perubahan Penggunaan Lahan Daerah Kabupaten Bengkayang 2015-2018 (Hasil Analisis Perubahan Penggunaan Lahan tahun 2014 dan 2015)

Tabel 2. Penggunaan Lahan Kabupaten Bengkayang Tahun 2019

\begin{tabular}{|c|c|c|c|c|c|c|c|c|c|c|}
\hline \multirow{2}{*}{\multicolumn{2}{|c|}{ Keterangan }} & \multicolumn{8}{|c|}{$2019(\mathrm{Ha})$} & \multirow[b]{2}{*}{ Total } \\
\hline & & APL & $\mathrm{HL}$ & HP & HPK & HPT & $\mathrm{CA}$ & $\mathrm{TN}$ & Tubuh Air & \\
\hline \multirow{9}{*}{ 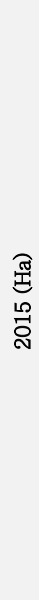 } & APL & $343,543.21$ & - & - & - & - & - & - & 0.00 & $343,543.21$ \\
\hline & $\mathrm{HL}$ & - & $35,274.89$ & 0.00 & - & 0.24 & - & 15.59 & - & $35,290.71$ \\
\hline & HP & - & 0.00 & $66,178.10$ & - & - & - & - & - & $66,178.10$ \\
\hline & HPK & - & - & - & $17,586.53$ & - & - & - & - & $17,586.53$ \\
\hline & HPT & - & 0.24 & - & - & $46,479.17$ & - & - & - & $46,479.41$ \\
\hline & $\mathrm{CA}$ & - & - & - & - & - & 816.03 & - & - & 816.03 \\
\hline & $\mathrm{TN}$ & - & 15.59 & - & - & - & - & $38,303.30$ & - & $38,318.88$ \\
\hline & $\begin{array}{l}\text { Tubuh } \\
\text { Air }\end{array}$ & - & - & - & - & - & - & - & 537.77 & 537.77 \\
\hline & Total & $343,543.21$ & $35,290.71$ & $66,178.10$ & $17,586.53$ & $46,479.41$ & 816.03 & $38,318.88$ & 537.77 & $548,750.64$ \\
\hline
\end{tabular}

Keterangan: APL= Area Penggunaan Lain; HL= Hutan Lindung; HP= Hutan Produksi; HPK= Hutan Produksi Konversi; HPT= Hutan Produksi Terbatas; TN=Taman Nasional. 
Tabel 3. Luas Lahan Menurut Penggunaan Lahan (Hektar) di Kabupaten Bengkayang [13] [31]

\begin{tabular}{|c|c|c|c|c|c|}
\hline No. & Penggunaan Lahan & 2012 & 2013 & 2014 & 2015 \\
\hline 1. & Lahan Pertanian & & & & \\
\hline 1.1 & Lahan Sawah & 41.178 & 41.828 & 38.713 & 34.835 \\
\hline a. & Irigasi & 17.815 & 15.503 & 14.111 & 10.930 \\
\hline b. & Tadah Hujan & 20.528 & 23.479 & 21.671 & 21.145 \\
\hline c. & Rawa Pasang Surut & 409 & 409 & 409 & 409 \\
\hline d. & Rawa Lebak & 2.426 & 2.437 & 2.522 & 2.351 \\
\hline 1.2 & Lahan Bukan Sawah & 463.215 & 450.908 & 442.804 & 446.677 \\
\hline a. & Tegal/Kebun & 39.949 & 41.108 & 40.080 & 41.283 \\
\hline b. & Ladang/Huma & 29.152 & 22.814 & 23.584 & 20.582 \\
\hline c. & Perkebunan & 133.989 & 134.814 & 136.335 & 142.835 \\
\hline d. & $\begin{array}{l}\text { Ditanami Pohon/ Hutan } \\
\text { Rakyat }\end{array}$ & 59.106 & 59.413 & 65.255 & 63.264 \\
\hline e. & $\begin{array}{l}\text { Padang Rumput/Peng- } \\
\text { gembalaan }\end{array}$ & 9.178 & 8.016 & 2.003 & 2.013 \\
\hline f. & Hutan Negara & & & & 122.493 \\
\hline g. & $\begin{array}{l}\text { Sementara } \\
\text { diusahakan }\end{array}$ & 44.808 & 49.112 & 49.690 & 41.105 \\
\hline h. & $\begin{array}{l}\text { Lainnya (tambak, kolam, } \\
\text { dll) }\end{array}$ & 147.033 & 135.631 & 125.857 & 13.102 \\
\hline \multirow[t]{2}{*}{2} & Lahan Bukan Pertanian & 35.237 & 46.894 & 58.113 & 58.118 \\
\hline & JUMLAH & 539.630 & 539.630 & 539.630 & 539.630 \\
\hline
\end{tabular}

Namun secara lebih luas, penggunaan lahan di Kabupaten Bengkayang selama kurun waktu 2015 sampai 2019 didominasi oleh Area Penggunaan Lain $(62,6 \%)$, hutan produksi $(12,1$ $\%)$, hutan produksi terbatas $(8,5 \%)$, taman nasional $(6,9 \%)$, hutan lindung $(6,4 \%)$, hutan produksi konversi $(3,2 \%)$, cagar alam $(0,2 \%)$, dan badan air $(0,1 \%)$ (Tabel 2$)$.

Data statistik perkembangan penggunaan lahan di wilayah Kabupaten Bengkayang pada tahun 2012-2015 diperlihatkan pada Tabel 3.

Tabel 3 diperoleh gambaran bahwa telah terjadi konversi lahan sawah menjadi perkebunan. Hal ini sesuai dengan hasil interpretasi data citra satelit yang menunjukkan bahwa terjadi penambahan luasan untuk kebun sawit yang terlihat khususnya di bagian tengah daratan di kabupaten Bengkayang.

Konversi hutan di dalam wilayah Kalimantan Barat, khususnya di wilayah kabupaten Bengkayang diperoleh data bahwa terdapat sebagian kecil perubahan penggunaan lahan, sedangkan sebagian besar mengubah menjadi sawah tadah hujan (ladang). Sedangkan beberapa perubahan besar yaitu kawasan hutan dikonversi menjadi perkebunan karet atau kelapa sawit dan potensi sumber daya kayu telah dieksploitasi[32].

Transformasi lahan sawah tadah hujan menjadi bentuk lain penggunaan lahan sangat bergantung pada modal yang dipunyai oleh pengusaha. Pola, arah perubahan dan intensitas perubahan penggunaan lahan di wilayah studi dapat dilihat pada Gambar 7 [32].

Perubahan perkebunan kelapa sawit menjadi penggunaan lahan lainnya sangat jarang dilakukan. Penelitian yang telah dilakukan juga membuktikan bahwa jarang sekali, perkebunan sawit beralih fungsi lahan lain, bahkan perkebunan sawit yang tidak produktif telah ditanami kembali dengan jenis tanaman baru.

Sedangkan kawasan hutan tertentu oleh masyarakat lokal cenderung digunakan sebagai perkebunan karet atau agroforestri, setelah dijadikan ladang (sawah tadah hujan) karena pada umumnya kebun kelapa sawit tidak diperbolehkan berada di kawasan hutan.

Sehubungan rencana program PLTN di pesisir kecamatan Sungai Raya Kepulauan, identifikasi penggunaan lahan saat ini sangat 
diperlukan sebagai database. Program tersebut tentunya akan merubah fungsi kawasan, yang semula kawasan perdesaan yang mempunyai kegiatan utama pertanian, termasuk pengelolaan sumber daya alam dengan susunan fungsi Kawasan sebagai tempat permukiman perdesaan, pelayanan jasa pemerintahan, pelayanan sosial, dan kegiatan ekonomi, akan dimungkinkan berubah menjadi Kawasan strategis provinsi yang penataan ruangnya diprioritaskan karena mempunyai pengaruh sangat penting dalam lingkup provinsi terhadap ekonomi, sosial, budaya, dan/atau lingkungan. Perubahan peruntukan lahan dari dominan perkebunan beralih ke industri akan menyebabkan tumbuh dan berkembang sarana dan prasarana diantaranya kebutuhan lahan untuk perkantoran, perumahan, pendidikan, kesehatan, peribadatan, pemukiman, keamanan dan sarana pendukung lainnya. Dengan demikian akan terjadi konversi lahan yang sangat signifikan dari semula perkebunan dan area untuk penggunaan lainnya menjadi sarana industri dan sarana pendukung lainnya. Antisipasi pemerintah daerah perlu dipersiapkan dalam mengoptimalkan manfaat ekonomi yang dapat diambil, khususnya untuk kesejahteraan masyarakat sekitar calon lokasi tapak PLTN, dan umumnya masyarakat Kalimantan Barat.

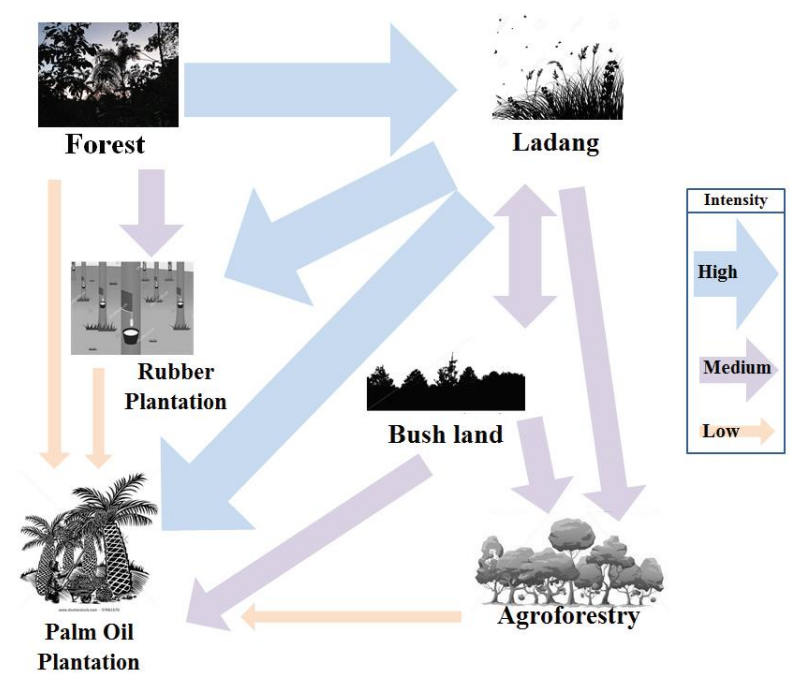

Gambar 7. Pola Perubahan Penggunaan Lahan[32].

Seperti juga penelitian yang telah dilakukan di Mesir terkait penggunaan lahan untuk program PLTN juga dilakukan dengan analisis yang sangat rinci dalam mengidentifikasi penggunaan lahan tapak
PLTN. Hal ini dimaksudkan untuk mendapatkan hasil yang optimal dan efisien dalam penggunaan lahan. Perencanaan harus mengintegrasikan informasi tentang kesesuaian lahan, permintaan untuk produk atau penggunaan alternatif, dan peluang untuk memenuhi permintaan tersebut atas lahan yang tersedia, sekarang dan di masa depan[2].

\section{KESIMPULAN}

Rencana Pembangunan prototipe PLTN di Desa Sungai Raya Kabupaten Bengkayang Kalimantan Barat akan berpengaruh terhadap pemanfaatan lahan. Pendataan terhadap penggunaan lahan dalam persiapan pembangunan PLTN di Kalimantan Barat sangat penting diidentifikasi. Penggunaan lahan di sekitar tapak pada radius $1 \mathrm{~km}$ adalah untuk pemukiman penduduk, lahan terbuka, perkebunan, perairan darat dan laut. Interpretasi citra Landsat, menunjukkan perubahan lahan antara tahun 2015 sampai tahun 2019 tidak terlihat adanya menunjukkan perubahan penggunaan lahan yang signifikan. Penggunaan lahan dominan di kabupaten Bengkayang adalah perkebunan. Penggunaan lahan yang paling banyak mengalami perubahan selama periode tahun 2015-2019 adalah hutan. Penggunaan lahan yang mengalami peningkatan adalah penggunaan perkebunan kelapa sawit.

Dengan kehadiran PLTN, akan terdapat konversi pemanfaatan lahan yaitu menyebabkan tumbuh dan berkembang sarana dan prasarana untuk perkantoran, perumahan, pendidikan, kesehatan, peribadatan, pemukiman, keamanan dan sarana pendukung lainnya.

\section{UCAPAN TERIMA KASIH}

Ucapan terima kasih disampaikan kepada PKSEN yang telah mendukung pendanaan penelitian ini dan semua pihak yang telah membantu dalam penelitian ini.

\section{DAFTAR ACUAN}

[1] PWC. May, 2018. Power in Indonesia: Investment and Taxation Guide $6^{\text {th }}$ Edition. PwC Indonesia, Jakarta. 
S. Algohary and A. I. . Aly, "A Proposal for National Efficient Land Use Planning for Power Plants in Egypt: An Integrated Nuclear Renewable Hybrid Energy System," Int. J. Currenrt Res., vol. 9, no. 07, 2017.

[3] H. Susiati, Y. S.B.S., K. Anzhar, B. Kironi, dan J. Mellawati, "Aplikasi Data Penginderaan Jauh Dan Sig Dalam Pemilihan Tapak Potensial Pltn Kalimantan Barat," J. Pengemb. Energi Nukl., vol. 17, no. 2, p. 121, 2015.

[4] A. H. Euis Etty Al Hakim, Heni Susiati, Sunarko, "Analisis Spasial Awal Lokasi Calon Tapak PLTN di Kalimantan Barat," in Pros. Semin. Nas. Infrastruktur Energi Nukl., pp. 173-179, 2019.

[5] P. K. S. E. N. BATAN, "Laporan Titik Nol Kalbar." Jakarta, 2019.

[6] NEA. June, 2010. Report on The Survey on Regulation of Site Selection and Preparation. NEA Commitee on Nuclear Regulatory Activity.

[7] S. Heni and H. Subagio, "Aplikasi Penginderaan Jauh dalam Pemetaan Penggunaan Lahan Detil Tapak RDE, PUSPIPTEK Serpong," J. Pengemb. Energi Nuklir, Vol. 18, Nomor 2, Desember 2016, vol. 18, no. 751, 2016.

[8] P. Jacob. March, 2014. Regulatory Guide 4.7: General Site Suitability Criteria for Nuclear Power Stations. United States Nuclear Regulatory Commission.

[9] B. W. Brook and C. J. A. Bradshaw, "Key Role for Nuclear Energy in Global Biodiversity Conservation”, Conservation Biology, Vol. 29, no. 3, pp. 702-712, 2014.

[10] A. Mikhalevich, "Development of works on the atomic energy using in the Republic of Belarus", At. Energiya, vol. 78, no. 4, pp. 236-243, 1995.

[11] K. Saito, "Temporal Change in Radiological Environments on Temporal Change in Radiological Environments in Fukushima”, Journal of Radiation Protection and Research, vol. 44, no. 4, pp. 128148, 2019.

[12] E. Colak, M. Candra, and F. Sunar, "The Use Of Multi-Temporal Sentinel Satelites In The Analysis Of Land Cover/ Land Use Changes Caused By The Nuclear Power Plant Construction," in The International Archives of the Photogrammetry, Remote Sensing and Spatial Information Sciences, vol. XLII-3/W8, no. 3-6 September, pp. 491-495, 2019.

[13] BPS. 2014. Statistik Penggunaan Lahan Kabupaten Bengkayang 2014, Katalog: 3, Bengkayang. BPS Kalimantan Barat, Pontianak.

[14] BPS. 2015. Statistik Penggunaan Lahan Kabupaten Bengkayang 2015, Katalog: BP., Bengkayang. BPS Kalimantan Barat, Pontianak.

[15] Y. Susanti and M. Helmi, "Analisa Perubahan Penggunaan Lahan Di Daerah Aliran Sungai Serayu Hulu Dengan Pengginderaan Jauh dan Sistem Informasi Geografis Analysis of Land Use Change in Upper Serayu Watersheds Using Remote Sensing and Geographic Information Systems", Bioedukasi: Jurnal Pendidikan Biologi, Vol. 13, No. 1, pp. 23-30, 2020.

[16] R. Nuraeni, S. Risma, P. Sitorus, and R. Panuju, "Analisis Perubahan Penggunaan Lahan dan Arahan Penggunaan Lahan Wilayah di Kabupaten Bandung," Buletin Tanah dan Lahan, Vol. 1, No. 1, pp. 79-85, 2017.
[17] Y. Setiawan and Y. Kunihiko, "Spatial modeling on land use change in regional scale of Java Island based-on biophysical characteristics," Journal of Natural Resources and Environmental Management, Vol. 10, No. 3, pp. 511-523, 2020.

[18] R. Adhiatma et al., "Perubahan dan prediksi penggunaan / penutupan lahan di Kabupaten Lampung Selatan," Journal of Natural Resources and Environmental Management vol. 10, no. 2, pp. 234-246, 2020.

[19] V. Y. Maki, "Identifikasi Penggunaan Lahan di Kecamatan Kalawat dengan Menggunakan Sistem Informasi Geografis Kabupaten Minahasa Utara," COCOS J. Ilm. Fak. Pertanian, Univ. Sam Ratulangi, Vol. 1, No. 4, 2014.

[20] BAPETEN. Peraturan Kepala Badan Pengawas Tenaga Nuklir No. 4 Tahun 2018 tentang Ketentuan Keselamatan Evaluasi Tapak Instalasi Nuklir. Badan Pengawas Tenaga Nuklir, Jakarta, 2018.

[21] IAEA Specific Safety Guide No. SSG-35: Site Survey and Site Selection for Nuclear Installations. International Atomic Energy Agency, Vienna, 2015.

[22] WNA. 2016. World Nuclear Performance Report 2016. World Nuclear Association, London.

[23] Fennovoima Ltd., October, 2008. Environmental Impact Assessment Report for a Nuclear Power Plant. Fennovoima Ltd, Helsinki.

[24] M. Mianto, A. Krisnohadi, and J. Gunawan, "Pemetaan Tanah Berdasarkan Kelas Lerengdan Penggunaan Lahan Di Desa Karimunting Kecamatan Sungai Raya Kepulauan Kabupaten Bengkayang,” J. Sains Mhs. Pertan., vol. Volume 8, 2019.

[25] R. Idris and Z. Abd. Latif, "GIS multi-criteria for power plant site selection," in Proceedings - 2012 IEEE Control and System Graduate Research Colloquium, ICSGRC 2012, 2012.

[26] U. E. Yunida. Desember, 2014. Laporan Akhir: Percepatan Pembangunan Sanitasi Permukiman Kabupaten Bengkayang. Kementrian Pekerjaan Umum Provinsi Kalimantan Barat, Pontianak.

[27] S. Gatot, "Analisis Pengelolaan Terumbu Karang Pada Kawasan Konservasi Laut Daerah ( KKLD ) Pulau Randayan dan Sekitarnya Kabupaten Bengkayang Provinsi Kalimantan Barat," in Tesis Program Magister Ilmu Lingkungan, Universitas Diponegoro, Semarang, 2008.

[28] KEMENKKP RI, Keputusan Menteri Kelautan dan Perikanan Republik Indonesia NOMOR 90/KEPMEN-KP/2020 Tentang Kawasan Konservasi Pesisir dan Pulau-Pulau Kecil randayan dan Perairan Sekitarnya di Provinsi Kalimantan Barat, Kementrian Kelautan dan Perikanan, Jakarta, 2019.

[29] GUBERNUR Kalbar, Peraturan Daerah Provinsi Kalimantan Barat No. 1 Tahun 2019, Tentang Rencana Zonasi Wilayah Pesisir Kalimantan Barat Tahun 2018-2038, Pemerintah Daerah Provinsi Kalimantan Barat, Pontianak, 2019.

[30] A. Dinilhuda, A. J. I. A. L. I. Akbar, and H. Herawati, "Potentials of Mangrove Ecosystem as Storage of Carbon for Global Warming Mitigation," BIODIVERSITAS, Vol. 21, Number 11, Novemb., vol. 21, no. 11, pp. 5353-5362, 2020.

[31] BPS, Statistik Penggunaan Lahan Kabupaten 
Mudjiono, Siti Alimah, dan Heni Susiati - Jurnal Pengembangan Energi Nuklir Vol. 22, No. 2, (2020) 101 - 110

Bengkayang Tahun 2015, Biro Pusat Statistik Provinsi Kalimantan Barat, Pontianak, 2015.

[32] P. G. Siregar, J. Supriatna, R. H. Koestoer, and D. Harmantyo, "System dynamics modeling of land use change in West Kalimantan, Indonesia," Biotropia (Bogor)., vol. 25, no. 2, pp. 103-111, 2018. 